\title{
ESCAPING THE TRAP: THE SIMPLIFIED APPLICATION OF EU LAW
}

\begin{abstract}
Libor Havelka*
Summary: While the case law of the Court of Justice of the European Union on the principles of the domestic application of EU law is attracting plenty of attention, little heed is given to the problems national courts have to face when implementing this case law. In this respect, this contribution looks at two aspects of the domestic application of EU law - the obligation to apply EU law ex officio and the application of EU law (namely the general principles of EU law and directives) between individuals. Its aim is to identify on specific examples from national legal practice the difficulties of national courts when they attempt to follow the case law of the Court of Justice and to put forward suggestions on how to simplify the role of national judges and, consequently, enhance the effective application of EU law in the Member States.
\end{abstract}

\section{Introduction}

The accession of a new Member State to the European Union places an onerous burden on all legal practitioners, state authorities and especially on national judges. The latter face a particularly difficult situation as they have now to deal on a daily basis with the application of EU law, including the case law of the Court of Justice of the European Union (hereinafter: the Court). Surprisingly enough, even after decades of application of EU law in the Member States, some fundamental questions relating to the domestic application of Union law remain unclear. The fundamental principles of domestic application are being eroded by a number of exceptions which make it difficult for national judges to acquire these principles and to use them in practice. The judgments in which the Court departs from its settled case law (eg the application of certain legal principles between individuals as a circumvention of the prohibition of the direct effect of directives in horizontal relations) usually receive plenty of attention in academic writing. This can give the impression that they have wider applicability than is the case. However, it is not easy for national courts, especially those of lower instances, to follow these developments given their heavy caseload, the pressure on them to reach a quick decision, and various other factors associated with national judicial systems.

Doctoral candidate, Masaryk University, Brno, Czech Republic. 
In this context, the paper focuses on two aspects of the domestic application of EU law - the obligation to apply EU law ex officio and the application of EU law between individuals. Sections 2 and 3 have the same structure. Firstly, part 1 of each section views the relevant case law of the Court. Part 2 demonstrates the divergences and difficulties resulting from the implementation of the Court's case law by national courts. Part 3 puts forward suggestions as to the possible simplification of the principles governing the ex officio application of EU law and the horizontal application. Section 3 underlines why these adjustments seem necessary. By trying to balance the requirements imposed on a national judge by the Court with what it is reasonable to require of and expect from national courts, the aim of this contribution is to offer a pragmatic view on how to deal with these issues from the standpoint of a national judge and to show in these two examples that there are possible ways to simplify the principles of the domestic application of EU law and, consequently, enhance the proper application of EU law in the Member States.

\section{WHEN: The obligation of a national judge to find and to apply the EU norm}

After examining a dossier and the facts of the case, the judge finds the applicable legal norm, and applies this norm to the facts as they are presented to the court by the parties. This is a (simplified) common working procedure of a judge, which can be subject to modifications depending on the stage of the proceedings (first instance, appeal, cassation), the applicable rules of procedure limiting the ambit of the dispute according to the instance, or, generally, the different character of the procedural systems in the Member States (from adversarial to inquisitorial). It is not unusual for a national judge to find the applicable legal norm within the national (or in some cases international) legal order and we can assume that this is what judges do on a daily basis. However, with the accession of the Member State to the EU, a new legal order of great magnitude has to be taken into consideration by the national judge. For the sake of simplicity, let us leave aside the complicated question of whether the case falls within the scope of EU law, ${ }^{1}$ which would normally be the first step in considering the application of EU law, and let us suppose that EU law is applicable.

\footnotetext{
In this respect, see for instance the following cases from various areas of EU law: Case C-299/95 Friedrich Kremzow v Austria [1997] ECR I-2629; Case C-328/04 Attila Vajnai [2005] ECR I-8577; Case C-142/05 Åklagaren v Percy Mickelsson and Joakim Roos [2009] ECR I-4273; Case C-457 / 09 Claude Chartry v Belgian State [2011] ECR I-819; Case C-34/09 Gerardo Ruiz Zambrano v Office national de l'emploi [2011] ECR I-1177; Case C-617/ 10 Åklagaren $v$ Hans Åkerberg Fransson [2013]; Case C-418/11 Texdata Software GmbH [2013]; Case C-206/13 Cruciano Siragusa v Regione Sicilia [2014]; Case C-628/11 International Jet Management $\mathrm{GmbH}$ [2014].
} 


\subsection{What the Court of Justice says}

Generally speaking, the Court has adopted the 'one-on-one' rule regarding the obligation of a national judge to raise points of EU law of his or her own motion. According to the 'one-on-one' rule, whenever national law requires courts to raise points of their own motion, the EU law follows in principle the national rule. ${ }^{2}$ This follows from the landmark van Schijndel case $^{3}$ in which the Court held that:

where, by virtue of domestic law, courts or tribunals must raise of their own motion points of law based on binding domestic rules which have not been raised by the parties, such an obligation also exists where binding Community rules are concerned $(\ldots) \cdot{ }^{4}$

Nonetheless, the same principle applies if the domestic law confers on courts the mere discretion to apply of their own motion binding rules of law. ${ }^{5}$ It appears that the Court does not distinguish between civil and administrative cases in this regard. ${ }^{6}$

The national procedural rules are subject to scrutiny under the wellknown and sometimes disputed principle of procedural autonomy in the form of effectiveness (national law must not be framed in such a way as to make it virtually impossible or excessively difficult to exercise the rights derived from EU law) and equivalence (claims based on EU law must not be subject to national rules which are less favourable than those governing similar domestic actions) tests. Although the Court in principle referred the obligation to apply EU law ex officio back to the national level by relying on the principle of equivalence, it introduced at the same time the 'contextual effectiveness test', sometimes called the 'procedural rule of reason'. The contextual approach to effectiveness requires examining a national rule, which potentially hinders the application of EU law, in context by considering the role of the provision in question in the procedure, its progress and special features, taking into account also the basic principles of the domestic judicial system, such as the principle of legal certainty, protection of the rights to defence and the proper conduct of

\footnotetext{
2 HJ Snijders and S Vogenauer (eds), Content and Meaning of National Law in the Context of Transnational Law (Sellier European Law Publishers 2009) 134.

3 Joined Cases C-430 \& 431/93 Jereon van Schijndel v Stichting Pensioenfonds voor Fysiotherapeuten [1995] ECR I-4705.

4 Van Schijndel (n 3) para 13.

5 Van Schijndel (n 3) para 14.

6 See Joined Cases C-222/05 J van der Weerd and Others, C-223/05 H de Rooy sr and $H$ de Rooy jr, C-224/05 Maatschap H en J van't Oever and Others, C-225/05 BJ van Middendorp v Minister van Landbouw, Natuur en Voedselkwaliteit [2007] ECR I-4233; or Case C-72/95 Aannemersbedrijf PK Kraaijeveld BV ea v Gedeputeerde Staten van Zuid-Holland [1996] ECR I-5403.
} 
procedure. ${ }^{7}$ It is the contextual effectiveness test which led to the different outcomes adopted by the Court in the judgments van Schijndel and Peterbroeck, rendered on the same day. ${ }^{8}$

The Court has stepped out beyond the realms of equivalence on a number of occasions and has found that national courts are obliged to go beyond the ambit of the dispute set by the parties and the requirements of national law in order to protect matters of public policy or other fundamental public interests. Basically, two lines of cases have emerged in this respect.

The first, manifested for instance in Eco Swiss or Manfredi, ${ }^{9}$ concerns EU competition law rules as matters of public policy. In Eco Swiss, the Court took the view that the national civil court, reviewing an arbitrational award, should annul the award if the award infringes EU competition law rules, even if in the domestic proceedings the national judge can of his or her own motion annul the award regarded as contrary to public policy; however, under national law, the non-application of competition law is not deemed contrary to public policy. Therefore, it is sometimes argued that the Court developed the concept of European public policy, comprising Articles 101 and 102 TFEU, which must be automatically applied by the national court. ${ }^{10}$

The second strand of cases concerns the ex officio application of EU consumer law. ${ }^{11}$ The Court held that national courts must abandon judicial passivity in order to ensure that consumer rights, mainly under

\footnotetext{
7 Van Schijndel (n 3) para 19; and Case C-312/93 Peterbroeck, Van Campenhout \& Cie SCS $v$ Belgian State [1995] ECR I-4599, para 14. See also H Schebesta, 'Does the National Court Know European Law? A Note on Ex Officio Application after Asturcom' (2010) 18 European Review of Private Law.

8 For a debate on the reasons which led the Court to the different solutions, see eg J Engström, 'National Courts' Obligation to Apply Community Law Ex Officio: The Court Showing New Respect for Party Autonomy and National Procedural Autonomy?' (2008) Review of European Administrative Law 67.

9 Case C-126/97 Eco Swiss China Ltd v Benetton International NV [1999] ECR I-3055; and Joined Cases C-295/04 Vincenzo Manfredi v Lloyd Adriatico Assicurazioni SpA, C-296/04 Antonio Cannito v Fondiaria Sai SpA, C-297/04 Nicolo Tricarico v Assitalia SpA, C-298/04 Pasqualina Murgolo v Assitalia SpA [2006] ECR I-6619.

10 A Kaczorowska, European Union Law (Routledge 2013) 250.

11 See notably Joined Cases C-240/98 Océano Grupo Editorial SA v Roció Murciano Quintero, C-241/98 Salvat Editores SA v José M. Sánchez Alcón Prades, C-242/98 José Luis Copano Badillo, C-243/98 Mohammed Berroane, C-244/98 Emilio Viñas Feliú [2000] ECR I-4941; and Cases C-473/00 Cofidis SA v Jean-Louis Fredout [2002] ECR I-10875; Case C-168/05 Elisa María Mostaza Claro v Centro Móvil Milenium SL [2006] ECR I-10421; Case C-429/05 Max Rampion and Marie-Jeanne Godard, née Rampion v Franfinance SA and K par K SAS [2007] ECR I-8017; Case C-40/08 Asturcom Telecomunicaciones SL v Cristina Rodriguez Nogueira [2009] ECR I-9579; Case C-488/11 Dirk Frederik Asbeek Brusse and Katarina de Man Garabito v Jahani BV [2013]. See also S Moracchini-Zeidenberg, 'La CJUE, le relevé d'office et les droits de la défense' (2013) 16 La Semaine Juridique Entreprise et Affaires.
} 
the Unfair Contract Terms Directive, are sufficiently protected..$^{12}$ For instance, in Mostaza Claro the Court stated that:

the nature and importance of the public interest underlying the protection which the Directive confers on consumers justify, moreover, the national court being required to assess of its own motion whether a contractual term is unfair, compensating in this way for the imbalance which exists between the consumer and the seller or supplier. ${ }^{13}$

In Asturcom, the Court found that Article 6 of the Unfair Contract Terms Directive must be regarded as a provision of equal standing to national rules which rank, within the domestic legal system, as rules of public policy. According to one commentator, the Court has created an indirect form of European public policy which, in contrast to true public policy, remains contingent on the national legal system having an exception for public policy. ${ }^{14}$ According to another, the Court treats certain provisions ${ }^{15}$ as an overarching concept of European public policy in the context of national procedure law. ${ }^{16}$

\subsection{Practice of national courts}

It is not easy to ascertain how national courts, in their practice, interpret and follow the rules set by the Court. Access especially to the case law of the courts of lower instances remains limited, although it is precisely their approach to the ex officio application of EU law which is of crucial importance. It is almost impossible to estimate the number of cases in which EU law should have been applied but where the national court did not do so, whether intentionally or unintentionally, and where the parties did not invoke EU law either. At times, we learn about these cases from the judgments of the higher courts, for instance when one of the parties raises EU law arguments at a later stage of the proceedings. Nonetheless, national procedural rules often limit the possibility to raise new legal and factual arguments before the appeal or cassation courts.

\footnotetext{
12 Council Directive 93/13/EEC of 5 April 1993 on unfair terms in consumer contracts [1993] OJ L95/29.

13 Mostaza Claro (n 11) para 38.

14 H Schebesta, 'Does the National Court Know European Law? A Note on Ex Officio Application after Asturcom' (2010) 18 European Review of Private Law.

15 Articles 101 and 102 TFEU; Article 6(1) Unfair Contract Terms Directive; Article 11(2) Consumer Credit Directive 87/102/EEC; and Article 4 Doorstep Selling Directive 85/577/ EEC.

16 See M Ebers, 'Mandatory Consumer Law, Ex Officio Application of European Union Law and Res Judicata: From Océano to Asturcom' (2010) 18 European Review of Private Law.
} 
This was the case in the recent decision of the Curia of Hungary (Hungarian Supreme Court), where the plaintiff submitted a petition for an extraordinary review, raising a point of law concerning collision with EU law which had not been raised before in the course of the main procedure. ${ }^{17}$ According to the plaintiff, the court of first instance should have recognised ex officio the contradiction between a national and EU law provision, namely Council Regulation 73/2009 establishing common rules for direct support schemes for farmers under the common agricultural policy and establishing certain support schemes for farmers. Under the Hungarian rules of civil procedure, an extraordinary review procedure before the Curia cannot be initiated by referring to a violation of law that was not addressed in the main procedure. The Curia viewed the relevant case law of the Court ${ }^{18}$ and recalled the contextual test derived from the Court's case law - namely that the entire procedure has to be taken into consideration in order to establish whether issues concerning the interpretation of EU law that were not raised during the main procedure can be raised before the review court. As there are no rules within the Hungarian civil procedure that restrict the application of EU law compared to national law, the Curia found that under such circumstances the review court is not obliged to examine new points of EU law raised by the parties for the first time in the review procedure. The review court should autonomously decide whether in such a case it examines the collision of the EU law with a national provision and whether it submits a preliminary reference to the Court.

The analysis of the Italian administrative courts' practice shows some interesting results. ${ }^{19}$ At the beginning of the 90 s, before the Court handed down its landmark judgments concerning the ex officio application of EU law, van Schijndel and Peterbroeck, the Italian administrative courts seemed fairly open to the application of (at that time) EC law of its own motion, even where the parties did not claim its violation. ${ }^{20}$ The Italian courts derived their argument from the Court's judgment in Verholen, ${ }^{21}$ but in fact they went even further by asserting that the na-

17 Case No Kfv IV 35, 402/2012/4, Curia of Hungary (Judgment of 4 June 2013).

18 The Curia referred to van Schijndel (n 3); Peterbroeck (n 7); Case C-33/76 Rewe-Zentralfinanz eG and Rewe-Zentral AG v Landwirtschaftskammer für das Saarland [1976] ECR I-1989; and Case C-536/11 Bundeswettbewerbsbehörde $v$ Donau Chemie AG and Others [2013].

19 M Eliantonio, 'The Application of EC Law Ex Officio: Some News From the Italian Administrative Courts' (2008) 2 Review of European Administrative Law.

20 Case No 532, Regional Administrative Court Lombardia (Judgment of 1 July 1993).

21 Joined Cases C-87-89/90 A Verholen and others $v$ Sociale Verzekeringsbank Amsterdam [1991] ECR I-3757. The Verholen judgment is referred to as the first decision of the Court dealing with the ex officio application of EC law. However, in Verholen, the Court merely stated that ' (...) the recognized right of an individual to rely, in certain conditions, before a national court, on a directive where the period for transposing it has expired does not pre- 
tional court was under the obligation to examine ex officio the compatibility of a national rule with EC law. ${ }^{22}$ Subsequently, after the Court's decisions in van Schijndel and Peterbroeck, Italian courts stepped back from their previous case law and began rather to emphasise the principle of party autonomy. ${ }^{23}$ For instance, according to the Council of State, if the grounds based on the alleged unlawfulness of the EC measure, ordering the Italian government to recover State aid, raised by the parties in order to claim the invalidity of a national administrative decision, are not explicitly put forward in accordance with the national procedural rules, a national court is not authorised to consider of its own motion this point. ${ }^{24}$ Likewise, the Italian administrative courts decided that they were not authorised to examine of their own motion the collision between a national administrative measure and EU rules on public procurement, which was not put forward by the applicant. ${ }^{25}$ Nonetheless, it has been argued that the Italian courts in their rulings adopted the Court's case law based on the principle of equivalence in an incomplete manner. More specifically, they did not perform the 'contextual effectiveness test' and did not examine the nature, aim and purpose of the rule in question, which raises doubts as to the sustainability and efficiency of the Court's case law if this turns out to be the prevalent approach of the national courts in other Member States, too. ${ }^{26}$

As for the Polish (civil) courts, they seem to adhere to the equivalence principle and derive the scope of the obligation to apply EU law ex officio mainly from the national procedure rules. ${ }^{27}$ Therefore, the obligation depends largely on the distinction between substantive and procedural law and on the stage of proceedings - the Polish courts of first and second instance should apply substantive EU law on their own motion whereas the second-instance courts are generally not obliged to take into account on their own motion infringements of EU procedural law. ${ }^{28}$ The situation is even more specific in the cassation proceedings before the Polish Supreme Court where Polish procedural law prevents the Supreme Court from controlling infringements which have not been indicated in the cas-

clude the power for the national court to take that directive into consideration even if the individual has not relied on it', without further elaboration of the ex officio application.

22 Case No 267, Regional Administrative Court Lombardia (Judgment of 5 April 1994); Case No 602 (Judgment of 16 July 1994); Case No 327, Council of State of Italia (Order of 8 May 1995).

${ }_{23}$ Case No 6657, Council of State of Italia (Judgment of 5 December 2002).

24 Case No 516, Council of State of Italia (Judgment of 16 February 2005).

25 Case No 1354, Regional Administrative Court of Sicily (Judgment of 30 May 2006).

26 Eliantonio (n 19).

${ }_{27}$ T Ereciński, 'When Must National Judges Raise European Law Issues on Their own Motion?' (2010) ERA Forum, November 2010.

28 With the exception of fundamental procedural questions such as the jurisdiction of Polish courts and the recognition and declaration of the enforceability of judgments. 
sation complaint, save in the case of the invalidity of the proceedings. ${ }^{29}$ However, the Supreme Court ruled that it can go beyond this limitation when the Supreme Court is obliged as the court of last instance to request a preliminary ruling in accordance with Article 267 TFEU, when the subject matter of the Polish and EU law provision is identical but the applicant refers solely to the Polish law and the indirect application of EU law is possible or when it is necessary to interpret national legal provisions in the light of EU law. ${ }^{30}$ The latter situations occur typically when the applicant indicates, as a ground for a cassation complaint, a national provision which incorrectly implements EU law or when the applicant refers to a national provision incompatible with the directly applicable EU norm. In line with this approach, the Supreme Court, for instance, allowed the claim of a male Polish conductor for early retirement although the Polish law granted this possibility only to female conductors. By raising the EU law ex officio, the Supreme Court held that the unjustified discrimination based on sex is contrary to Council Directive 79/7/EEC. ${ }^{31}$

In France, trial judges (juges $d u$ fond) and judges of the cassation jurisdictions are obliged to raise purely legal grounds (moyens de pur droit) stemming from EU law in the same manner as the legal grounds based on national law, according to the principle of equivalence set by the Court. The obligation of a judge to apply ex officio a legal norm to the facts follows from the relevant articles of the French Code of Civil Procedure. ${ }^{32}$ On the other hand, the Code of Civil Procedure also stresses in its Article 16 the adversarial aspect of the procedure, putting the French system somewhere in between party autonomy and judicial passivity. ${ }^{33}$ The judgment of the appellate court, in which the judge does not raise the (purely) legal ground stemming from EU law, is at risk of being annulled by the Court of Cassation, be it because the applicant puts forward an EU law argument for the first time in the proceedings before the Court of Cassation, or the Court of Cassation itself raises the EU law grounds

\footnotetext{
29 Article 398 of the Polish Code of Civil Procedure.

30 Case No II PK 17/06, Supreme Court of Poland (Judgment of 18 December 2006); and Ereciński (n 27).

31 Council Directive 79/7/EEC of 19 December 1978 on the progressive implementation of the principle of equal treatment for men and women in matters of social security [1979] OJ L6/24. See Case No I UK 182/07, Supreme Court of Poland (Judgment of 4 January 2008); and T Ereciński (n 27).

32 Article 12 says: The judge settles the dispute in accordance with the rules of law applicable thereto. He must give or restore their proper legal definitions to the disputed facts and deeds notwithstanding the denominations given by the parties [...]'. Articles 619 and 620 govern the scope of the review by the Court of Cassation.

33 Article 16 paras 2 and 3 say: 'In his decision, the judge may take into consideration grounds, explanations and documents, relied upon or produced by the parties only if the parties had an opportunity to discuss them in an adversarial manner. He shall not base his decision on legal arguments that he has raised sua ponte without having first invited the parties to comment thereon'.
} 
of its own motion. The situation is somewhat different when it comes to raising of its motion a combination of factual and legal grounds (moyens mélangés de fait et de droit). Trial judges may raise the combination of factual and legal grounds under the national law; however, within the ambit of the dispute they are required to do so under EU law by virtue of the principle of effectiveness. In principle, such an obligation does not apply to the Court of Cassation as its judges are judges of the law juges $d u$ droit) and not of the facts. ${ }^{34}$

There are a number of judgments of the Court of Cassation where it raised EU points of law of its own motion. It invoked ex officio, for instance, the articles of the Treaty on the free movement of goods and on the prohibition of customs duties or charges having equivalent effect in order to liberate an undertaking from the obligation to pay a transit charge, ${ }^{35}$ or the Social Security Schemes Regulation. ${ }^{36}$ The Court of Cassation also engaged itself in the interpretation of national law in conformity with EU law. For instance, it interpreted of its own motion the relevant provisions of the Labour Code in conformity with the Directive on the safeguarding of employees' rights in the event of transfers of undertakings, and annulled the challenged judgments; ${ }^{37}$ in a similar manner, the Court of Cassation interpreted the national law in conformity with the directive concerning the safety of workers. ${ }^{38}$ However, the intricate question of the application of the iura novit curia principle under the French law came through initially in the area of consumer law, where the French legislator, after the Rampion case, amended the relevant articles of the Consumer Code, enabling the courts to raise ex officio all the provisions codified in the Consumer Code regardless of their status of public policy, and the Cassation Court subsequently reversed its former position. ${ }^{39}$

\footnotetext{
34 See, also for an overview of the case law of the Court of Cassation on the matter, D Simon, 'La pratique de la fonction juridictionnelle', 3e partie du rapport annuel de la Cour de cassation de 2006 (la Cour de cassation et la construction juridique européenne) n 1-2-2-1.

35 Case No 91-18964, Court of Cassation (Judgment of 27 February 1996). See also the Court's ruling in Case C-16/94 Édouard Dubois et Fils and Général Cargo Services SA [1995] ECR I-2432.

36 Regulation (EEC) No 1408/71 of the Council of 14 June 1971 on the application of social security schemes to employed persons and their families moving within the Community. See Case No 98-46422, Court of Cassation (Judgment of 5 June 2001).

37 Council Directive 98/50/EC of 29 June 1998 amending Directive 77/187/EEC on the approximation of the laws of the Member States relating to the safeguarding of employees' rights in the event of transfers of undertakings, businesses or parts of businesses OJ L201/88. See Court of Cassation, Judgment of 24 February 2004 No 01-40714, 01-40715, 01-40716, 01-43.982, 01-40717.

38 Council Directive 89/391/EEC of 12 June 1989 on the introduction of measures to encourage improvements in the safety and health of workers at work OJ L183/1. See Case No 05-41555, Court of Cassation (Judgment of 28 February 2006).

39 Case No 05-20176, Court of Cassation (Judgment of 22 January 2009); Case No 11 12160 (Judgment of 12 April 2012); Case No 11-17528 (Judgment of 12 July 2012).
} 


\subsection{Simplifying the obligation to apply EU law ex officio}

As Advocate General Jacobs argued in his opinion in Van Schijndel, if the view were taken that national procedural rules must always yield to Union law, it would unduly subvert the established principles underlying the legal systems of the Member States..$^{40}$ In the absence of harmonised rules on remedies, procedure and time limits, a degree of disparity in the application of EU law is inevitable. ${ }^{41}$ Although the differences between procedures within the Member States might not be as great as believed, ${ }^{42}$ the outlined practice in some of the above-mentioned national jurisdictions shows that considerable divergences in raising points of law of their own motion still exist among national legal systems. An obligation to raise EU law ex officio regardless of the national procedural rules, if imposed on national judges by the Court, would probably be heavily disregarded. The is all the more true if we consider how often national courts overlook the requirements of the Court under the current regime, based predominantly on the principle of equivalence which (in most cases) does not require national judges to set aside national procedural rules. As previously mentioned, it is almost impossible to estimate the number of cases in which EU law should have been applied ex officio but where the national courts did not do so. There are, however, some indications that the number of such cases remains significant (except in specialised jurisdictions, eg competition law). For instance, the International Department of the Czech Supreme Court conducted two surveys concerning the application of EU law by the Czech civil courts during 2004-2008 and 2009-2011. The courts of lower instances were asked to provide the International Department with the judgments in which they applied EU law during the respective periods. Regarding the 2009-2011 period, out of 98 courts requested, 16 courts reported that EU law had not been applied in any single case..$^{43}$ Certainly, it would not be valid to make generalisations on the courts in the whole of the EU based only on the data collected in one of the (relatively recent) Member States. Some data on the familiarity of national judges with EU law, however, suggest that the situation is perhaps not hugely different, even in some old Member States. According to a survey in which around 300 judges from the Netherlands and Germany participated, $45.2 \%$ of respondents stated that it was totally unclear to them when they must apply EU law ex officio. ${ }^{44}$ Furthermore,

\footnotetext{
40 Joined Cases C-430 \& 431/93 Jereon van Schijndel $v$ Stichting Pensioenfonds voor Fysiotherapeuten ECR I-4705, Opinion of AG Jacobs, para 27.

41 ibid, para 45.

42 ibid, para 34.

43 L Havelka, A Kondelová, A Pavel, K Šipulová, Aplikace unijního práva českými civilními soudy 2009-2011 [The Application of Union Law by the Czech Civil Courts 2009-2011] (Supreme Court of the Czech Republic 2013).

44 See the summary report of a survey on the knowledge of EU law among Dutch and Ger-
} 
some indications confirming this presumption can be found in the relevant literature. For instance, Sacha Prechal, who derived her conclusions predominantly from personal experience and contacts with the national judiciary, mentions that it seems that even after decades of EU membership national judges (including the younger generation) are still struggling somewhat with EU law rather than smoothly applying it. ${ }^{45}$

Under these circumstances, it would seem more appropriate to keep the principles governing the ex officio application of EU law rather simple. The contextual effectiveness test and competition and consumer law exceptions presumably do not fit into this approach. As for the contextual effectiveness test introduced by the Court, judgments of national courts can be found which at least refer to or even try to perform the test (the above-mentioned decision of the Curia of Hungary) but it is doubtful whether we can assume that the test has become a standard technique used by the judges when they assess whether the national procedural rules hinder the ex officio application of EU law. The test has been criticised mainly for the lack of predictability and impracticality, and has even been marked as a 'practically impossible - excessively difficult' test. ${ }^{46}$ Likewise, the ambiguous specification of the areas of law (so far, competition and consumer law, and it is not clear whether the Court will expand this approach to other areas of EU law in the future), where the principle of equivalence requires national courts to disregard a national rule and to apply EU law ex officio, contributes to a weakening of legal certainty and may cause undesirable side effects. For instance, under Dutch law a judge cannot go beyond the ambit of the dispute, with the exception of matters of public order; as consumer law is not regarded as a matter of public order, the consumer should invoke the unfairness of a term so that the court could disregard the term. The case law of the Court, which requires national courts to review ex officio potentially unfair terms in consumer contracts, led to an intensive debate in legal doctrine and to conflicting judgments of courts of lower instances, until the Hoge Raad (Supreme Court) ruled on the matter in September 2013. ${ }^{47}$ Additionally, the question of how to implement this case law of the Court, which would intrude rather extensively in national procedural autonomy,

man judges 'The court is not so sure about the law - national judges and EU law' (2010) <http://legalresearchnetwork.eu/wp-content/uploads/2011/10/PaperTobiasNowakGroningen.doc> accessed 31 March 2014.

45 S Prechal, 'National Courts in EU Judicial Structures' (2007) Yearbook of European Law 2006, 432 .

46 A Lo Faro, 'Judicial Enforcement of EC Labour Law: Time Limits, Burden of Proof, Ex Officio Application of EC Law' (2002) I Working Papers Centro studi di Diritto del Lavoro Europeo.

47 Case No 12/00395, Supreme Court of the Netherlands (Judgment of 13 September 2013). 
may result in national courts overlooking the EU law dimension in the relevant cases. ${ }^{48}$

It appears that in the debate about competing principles, the contextual assessment of the norms, and (European) public order or public interest, the core of the problem has been somehow overshadowed. The question rather scarcely raised is to which EU norms the obligation of the ex officio application should relate, or, in other words, what would it be reasonable to require from the national judges in this respect. The issue which arises in this regard is how to classify the EU norms, and how to lay down the demarcation lines between their categories in order to determine which points of EU law should be obligatorily raised by national judges. It is not generally disputed that when a national judge is obliged under national law to find the applicable norm and to apply it to the facts presented by the parties, he or she is obliged to search for the applicable norm not only within the national legal system, but also to take into account EU regulations, which are legally binding in every Member State, similar to national laws. ${ }^{49}$ The situation remains more ambiguous when it comes to ex officio conform interpretation by national courts. The prevalent view is seemingly in favour of a broad understanding of the ex officio obligation, so when national courts have to raise EU law of their own motion, they also have to interpret national law in the light of the EU norms in line with the doctrine of consistent interpretation (indirect effect). ${ }^{50}$ Needless to say, in practice, this mostly amounts to a demand to find wrongly implemented or non-implemented directives and to use them as an interpretative tool.

In order to facilitate comprehension of the domestic application of EU law for national judges, the basic principles of the domestic application of EU law are sometimes likened to the usage of principles which are already known to judges in the domestic legal orders. The doctrine of conform interpretation is considered to resemble conform interpretation in the light of the Constitution or the interpretation of domestic laws in

\footnotetext{
48 At times, the national court is well aware of the European element in the (consumer) case at hand and achieves the result sought by the directive without expressly referring to it. See Case No II Pl. ÚS 3406/10, Constitutional Court of the Czech Republic (Judgment of 14 March 2013). This is also not a fully desirable outcome, especially in the case of courts of higher instances, whose judgments should have a pedagogical impact on lower courts.

49 And, possibly also EU Treaties, as the Court has derived the direct effect of some of its provisions on a number of occasions.

50 For instance, see the Opinion of AG Darmon in Verholen, where he held that the primacy of Community law cannot be left to the discretion of the national courts, without the risk of its uniform application being seriously compromised; therefore, a national court is under the duty to raise of its own motion the existence of a Community rule with regard both to Community rules which have direct effect and to those which do not have such effect. Joined Cases C-87-89/90 A Verholen and others v Sociale Verzekeringsbank Amsterdam ECR I-3782, Opinion of AG Darmon.
} 
line with international treaties. In this respect, it should be recalled that when national judges examine the conformity of national ordinary legislation with EU law, they compare national provisions against a backdrop of a totally different magnitude. It can hardly be contested that national law is increasingly based on, or at least influenced by, EU law. The national legislation is becoming more and more 'Europeanised'. There is probably no accurate way of calculating the percentage of national laws based on EU legislation. A survey of the House of Commons Library elaborated in 2010 estimates that the proportion of national laws based on EU legislation in EU Member States varies widely, ranging from 6\% to $84 \% .{ }^{51}$ The data show that even though the numbers of domestic laws directly influenced by Brussels are sometimes overestimated, a significant part of national legal orders has its origin in EU law.

Sometimes it is clear from the text of a law that the concrete norm at hand is a transposition of EU legislation. Legislative drafting guidelines and instructions in the Member States may also prescribe that it be stated in the text of the law that the adopted legislation has its origin in EU law. ${ }^{52}$ However, it is difficult or at times almost impossible to ascertain at first glance that the judge is applying a transposed norm. Regarding harmonious interpretation, in the survey on the knowledge of EU law among Dutch and German judges mentioned in footnote $44,37 \%$ of all judges said they did not know what the Court expects of them as to the interpretation of national law in harmony with EU directives, and 41\% answered it was only partly clear to them. One of the commentaries also aimed at the difficulties in identifying the issues of EU law - when a judge does not know that national law is based on a directive, he or she cannot interpret it in harmony with the directive. The scope of EU law is expanding rapidly, and the times when European legislation consisted mainly of economic, fiscal or social regulations are long gone. From the perspective of a national judge, the obligation to ex officio raise points of EU law in an absolute form would amount to requiring national judges to verify in advance almost every provision of national law before applying it, in order to ascertain whether it is an implementation of EU legislation or not.

In order to bring the requirements concerning the ex officio application of EU law, imposed on national judges, more in line with reality, it

\footnotetext{
51 The proportion of EU-based national law depends on various factors, including the area of law concerned, the length of EU membership, the methods of transposition, etc. See further House of Commons Library, 'How Much Legislation Comes from Europe?' (2010) Research Paper 10/62, 13 October 2010 <www.parliament.uk/briefing-papers/RP10-62. pdf $>$ accessed 31 March 2014.

52 See for instance the Guidelines for the fulfilment of legislative obligations arising out of the Czech Republic's Membership in the European Union <https://isap.vlada.cz/homepage2.nsf/pages/esd/\$file/mp.pdfs accessed 31 March 2014. Moreover, national implementation measures must be notified to the Commission.
} 
seems appropriate to simplify these requirements. With regard to the expansion of EU law (and the limited knowledge of EU law among national judges related thereto) and the burdensome obligation of harmonious interpretation (which hardly resembles the other types of harmonious interpretation that national judges are accustomed to), the question is whether it would not be preferable to exempt national judges from the duty to interpret ex officio national law in the light of EU directives. ${ }^{53}$ Inevitably, this approach would warrant increased effort on the part of the EU institutions and national authorities in order to ensure the high conformity of the transposing measures with the directives. The Commission has already put in place some arrangements to tackle the compliance deficit, such as the EU Pilot platform. ${ }^{54}$ However, it is sometimes argued that the Commission lacks sufficient capacity to deal comprehensively with this task and to enforce the correct implementation of directives. ${ }^{55}$ The European Parliament is also involved in assessing the tools developed at EU level to promote compliance, such as the infringement procedure, correlation tables, scoreboards, transposition and implementation plans, inspections, etc. ${ }^{56}$ The Parliament also called in the past for increased cooperation between national parliaments and the European Parliament to reinforce control of transposition measures at the national level. ${ }^{57}$ These efforts need to be strengthened so as to minimise the risk of applying incorrectly transposed national legislation and to prevent divergences in national jurisdictions. The Court may also contribute to clarifying and simplifying the ex officio application of EU law. It should very carefully consider when the principle of effectiveness of EU law requires national courts to go beyond national procedural rules and to precisely define these cases in order to provide national courts with unequivocal and sufficiently clear guidelines.

These steps would certainly not bring a solution to all the problems described above. National judges would still have to become familiar with a significant part of EU legislation. Still, it would arguably make the requirements imposed on national courts more feasible.

\footnotetext{
53 Naturally, national judges would remain obliged to take into consideration the directives at the request of the parties invoking their indirect or vertical direct effect (if national law permits parties to raise this argument at the given stage of the proceedings).

54 See the Commission's communication 'A Europe of results - Applying Community law' COM (2007) 502 final; and the Commission's '30 ${ }^{\text {th }}$ Annual Report on monitoring the application of EU law' COM (2013) 726.

55 B Steunenberg, 'Is Big Brother Watching? Commission Oversight of the National Implementation of EU Directives' (2010) 11 European Union Politics.

56 European Parliament, Tools for Ensuring Implementation and Application of EU Law and Evaluation of their Effectiveness' (2013) PE 493.014.

57 European Parliament, 'Comparative Study on the Transposition of EC Law in the Member States' (2007) PE 378.294.
} 


\section{HOW: The horizontal application of EU law}

Once the relevant EU norm is found and the national judge decides to apply it, another delicate issue appears - the effects of EU law within the national legal system. Certainly, plenty of attention has been paid over the years to the primacy of EU law, its direct and indirect effect, state liability for breaches of EU law, and related issues. All of these principles have their limits, exceptions and yet unexplored connotations. Nonetheless, especially one aspect of the principles of the domestic application of EU law remains particularly unclear in spite of its great significance for national legal practice - the horizontal effects of EU law, ie the application of certain EU legislation between individuals, namely directives and general principles of EU law. It has become clear that directives and general principles of EU law may produce different types of horizontal effect, particularly indirect or incidental horizontal effect. In recent years, the opacity of the issue at hand has increased with the legally binding Charter of Fundamental Rights of the EU (hereinafter: the Charter), containing rights which are in certain cases further implemented through directives, raising again the question of the (potential) horizontal effect of the rights enshrined in directives. Taking account of the growing relevance of these developments, it is essential to provide national judges who deal increasingly with these cases with appropriate guidance.

\subsection{What the Court of Justice says}

For the sake of simplicity, we will set aside the horizontal application of Treaty provisions, ${ }^{58}$ regulations, ${ }^{59}$ and decisions, ${ }^{60}$ as they do not pose significant problems. Attention will mainly be given, as previously suggested, to directives and general principles of EU law.

\footnotetext{
58 The Court has established direct effect of Treaty provisions repeatedly in its case law, including their horizontal direct effect. See for instance Cases C-36/74 BNO Walrave and LJN Koch $v$ Association Union cycliste internationale, Koninklijke Nederlandsche Wielren Unie and Federación Española Ciclismo [1974]; C-281/98 Roman Angonese v Cassa di Risparmio di Bolzano SpA [2000] ECR I-4139; C-112/00 Eugen Schmidberger, Internationale Transporte und Planzüge $v$ Republik Österreich [2003] ECR I-5659; C-438/05 International Transport Workers' Federation and Finnish Seamen's Union $v$ Viking Line ABP and OÜ Viking Line Eesti [2007] ECR I-10779.

59 The direct effect of regulations is generally presumed, including horizontal relationships. See Article 288 TFEU.

60 The direct effect of decisions depends generally on their nature - decisions addressed to an individual (or individuals) are binding on this individual or individuals; decisions addressed to a Member State might produce vertical direct effect (see Case C-156/91 Hansa Fleisch Ernst Mundt GmbH \& Co KG proti Landrat des Kreises Schleswig-Flensburg [1992] ECR I-5567), although their horizontal direct effect is excluded (see Case C-80/06 Carp Snc di L Moleri e V Corsi $v$ Ecorad Srl [2007] ECR I-4473).
} 
Since the Court's decision in Marshall, ${ }^{61}$ the classic narrative says that the direct effect of directives cannot be extended to horizontal situations - directives are in the first place addressed to the Member States, which implies that individuals are not obliged to follow them. For that reason, directives cannot lay duties on individuals. A number of exceptions to this general rule have been introduced by the Court. The most important of these is the horizontal application of the general principles of EU law and the indirect effect of directives (conform interpretation).

In its (in)famous decision in Mangold, ${ }^{62}$ the Court held that the general principle of equality is capable of horizontal direct effect, stating that:

...it is the responsibility of the national court, hearing a dispute involving the principle of non-discrimination in respect of age, to provide, in a case within its jurisdiction, the legal protection which individuals derive from the rules of Community law and to ensure that those rules are fully effective, setting aside any provision of national law which may conflict with that law. ${ }^{63}$

In Mangold, the Court noted that the directive ${ }^{64}$ at hand (whose period prescribed for transposition had not yet expired at the material time) did not itself lay down the general principle, but only established a general framework for combating discrimination on the grounds covered by the directive ${ }^{65}$ In subsequent case law, namely in Kücükdeveci, ${ }^{66}$ the Court further specified (in relation to the same principle and directive, whose implementation period had already expired at that time) that the principle of non-discrimination in respect of age can apply if the case falls within the scope of EU law which, inter alia, requires the expiry of the implementation period of the directive. ${ }^{67}$ Once again, the directive does not lay down the principle of equal treatment but merely gives expression to it. ${ }^{68}$

Regarding the line of cases concerning the application of general principles of EU law between private persons, in which the matter was

${ }_{61}$ Case C-152/84 MH Marshall v Southampton and South-West Hampshire Area Health Authority [1986] ECR 723.

62 Case C-144/04 Werner Mangold v Rüdiger Helm [2005] ECR I-9981.

63 Mangold (n 62) para 77.

${ }^{64}$ Council Directive 2000/78/EC of 27 November 2000 establishing a general framework for equal treatment in employment and occupation [2000] OJ L303/16.

65 For a critical assessment of Mangold, see for instance T Papadopoulos 'Criticizing the Horizontal Direct Effect of the EU General Principle of Equality' (2011) 4 European Human Rights Law Review.

66 Case C-555/07 Seda Kücükdeveci v Swedex GmbH \& Co KG [2010] ECR I-365.

67 ibid, paras 23-25.

68 ibid, para 50. 
brought within the scope of the EU law by virtue of the Treaties, ${ }^{69}$ the question arose about what can in fact determine the applicability of general principles. As the Court ruled that in order to attract the application of a general principle, the Treaty provision bringing the matter within the scope of EU law must have direct effect, ${ }^{70}$ one can ask why, if a rule falls within the scope of a Treaty provision without direct effect, it should not attract the application of the general principle but that the result is reversed when it comes to a directive without direct effect. ${ }^{71}$ Another controversial issue is the extent of the applicability of general principles, and, more concretely, whether these principles can merely exclude conflicting national rules or even substitute them. This raises the question about why the directive cannot impose exclusionary effects, but such effects can be imposed by virtue of a general principle triggered by that directive. ${ }^{72}$

These issues have become even more relevant with the legally binding Charter with regard to the general principles of EU law, which are embodied in the articles of the Charter. The text of the Charter distinguishes between 'rights' and 'principles'. In general, no subjective right can be derived from provisions considered as principles. Nevertheless, certain implementing acts concretising a principle (eg a directive) can serve as a benchmark for the legality of national (implementing) acts. In a recent case, Association de médiation sociale, ${ }^{73}$ concerning an incorrectly implemented directive which specified the rights enshrined in Article 27 of the Charter (considered a principle under the Charter's terminology), the Court took the view that a person whose rights are specified in a directive not properly implemented and who is in conflict with another private party cannot rely on the directive before the (national) court if the rights are not precisely named in the Charter. In other words, the Court did not grant the horizontal direct effect of the worker's right to information and consultation enshrined in the Charter. ${ }^{74}$ It has to be added that

\footnotetext{
69 Cases C-368/95 Vereinigte Familiapress Zeitungsverlags- und vertriebs GmbH $v$ Heinrich Bauer Verlag [1997] ECR I-3689; C-438/05 International Transport Workers' Federation and Finnish Seamen's Union v Viking Line ABP and OÜ Viking Line Eesti [2007] ECR I-10779; C-341/05 Laval un Partneri Ltd $v$ Svenska Byggnadsarbetareförbundet, Svenska Byggnadsarbetareförbundets avdelning 1, Byggettan and Svenska Elektrikerförbundet [2007] ECR I-11767.

70 Case C-427/06 Birgit Bartsch v Bosch und Siemens Hausgeräte (BSH) Altersfürsorge $\mathrm{GmbH}$ [2008] ECR I-7245.

${ }^{71}$ See E Spaventa, The Horizontal Application of Fundamental Rights as General Principles of Union Law' in Anthony Arnull and others (eds), A Constitutional Order of States: Essays in Honour of Alan Dashwood (Hart Publishing 2011).

72 ibid.

73 Case C-176/12 Association de médiation sociale v Union locale des syndicats CGT and Others (15 January 2014).

${ }^{74}$ See commentary in F Riem, 'L'invocabilité de la Charte des droits fondamentaux et le droit du travail: "avec toi je suis toujours dans l'incertain"” [2014] ELSJ <http://www.gdrelsj.eu/2014/01/25/elsj/linvocabilite-de-la-charte-des-droits-fondamentaux-et-le-droitdu-travail-avec-toi-je-suis-toujours-dans-lincertain/> accessed 31 March 2014.
} 
Advocate General Villalón in his Opinion suggested allowing some sort of horizontal direct effect of a directive implementing a principle embedded in the Charter; ${ }^{75}$ it is therefore apparent that opinions of this kind exist in the Court and one cannot be fully sure about the future developments of the Court's case law.

The principle of indirect effect does not encompass only the harmonious interpretation of national law in conformity with directives; all national law, including provisions not specifically enacted for the purposes of implementation, should be interpreted in accordance with all EU law. ${ }^{76}$ It is, however, the indirect effect of directives which usually entails difficulties in the practice of national courts, taking into account its possible horizontal application. Given its less 'intrusive' nature from the vantage point of the national legal order compared to direct effect, indirect effect may seem less controversial and more frequently used, which all the more underlines the importance of this principle. Under the doctrine of indirect effect, national authorities, including courts, should interpret national law, as far as possible, in the light of the wording and the purpose of the directive concerned in order to achieve the result sought by the directive. ${ }^{77}$ The principle of interpreting national law in conformity with EU law has certain limitations, namely interpretative methods recognised by national law, ${ }^{78}$ general principles of law, interpretation contra legem, ${ }^{79}$ and non-expiration of the implementation period. ${ }^{80}$ The most controversial and problematic feature of the indirect effect of directives is that in the Court's interpretation, indirect effect sometimes almost amounts to direct horizontal application, regardless of the contra legem limitation. ${ }^{81}$

75 Case C-176/12 Association de médiation sociale $v$ Union locale des syndicats CGT and Others (18 July 2013), Opinion of AG Villalón.

76 For the sake of completeness, it has to be added that conform interpretation is not strictly limited to the EU law norms without direct effect. If appropriate, directly effective EU provisions may also be used for conform interpretation.

77 Cases C-14/83 Sabine von Colson and Elisabeth Kamann v Land Nordrhein-Westfalen [1984] ECR I-1891; C-106/89 Marleasing SA v La Comercial Internacional de Alimentacion SA [1990] ECR I-4135; C-397/01 Bernhard Pfeiffer, Wilhelm Roith (C-398/01), Albert Süß (C-399/01), Michael Winter (C-400/01), Klaus Nestvogel (C-401/01), Roswitha Zeller (C402/01) and Matthias Döbele (C-403/01) v Deutsches Rotes Kreuz, Kreisverband Waldshut eV [2004] ECR I-8835; C-282/10 Maribel Dominguez v Centre informatique du Centre Ouest Atlantique and Préfet de la région Centre [2012].

78 Case C-212/04 Konstantinos Adeneler and Others $v$ Ellinikos Organismos Galaktos [2006] ECR I-6057.

79 Dominguez (n 77) para. 25.

80 Adeneler (n 78) para. 115.

81 See for instance Cases C-177/88 Elisabeth Johanna Pacifica Dekker $v$ Stichting Vormingscentrum voor Jong Volwassenen (VJV-Centrum) Plus [1990] ECR I-3941; C-365/98 Brinkmann Tabakfabriken GmbH v Hauptzollamt Bielefeld [2000] ECR I-4619; or some cases concerning the indirect effect of the Unfair Consumer Terms Directive mentioned in footnote 11. 
The Court also found other ways to reach into horizontal relationships. In triangular situations, a private party invokes a directive imposing an obligation on a state which results in affecting the position of a third private party. ${ }^{82}$ Furthermore, the Court broadened the notion of the 'state' which allows the directives to be invoked against a wider range of entities. $^{83}$

\subsection{Practice of National Courts}

When looking at the case law of national courts on conform interpretation, it appears that contra legem interpretation is the principal limitation posing problems for national courts. According to a simple rule, contra legem interpretation occurs when the court gives effect to the EU norm although the EU norm and national norm would contradict each other. However, the reality does not always fit the theoretical axioms. Conform interpretation appears to be a widespread technique used by the national courts; there are probably thousands of decisions where national courts have interpreted national law in the light of EU law which makes it difficult to derive some valuable generalisations from their practice. In any case, it can be useful to look at least at some examples of how national courts deal with indirect effect and contra legem interpretation.

In the Netherlands, the Council of State has had its say repeatedly on the interpretation of Dutch law in conformity with EU law. In a case concerning the availability of the location of GMO experiments to the public, Dutch law required this information to be kept secret whereas the relevant directive required these data to be made available. ${ }^{84}$ Under these circumstances, the Council of State ruled that the national law cannot be interpreted in conformity with the directive. ${ }^{85}$ In another case, the District Court of Utrecht had to rule on the conformity of the Dutch Nature Conservation Law and the Wild Birds Directive. ${ }^{86}$ In response to the damage caused by Canadian geese, Dutch authorities had granted permission for gassing them. Under the Wild Birds Directive, the arrangements or methods authorised for the capture or killing of the birds must be specified; as

\footnotetext{
82 Cases C-201/02 The Queen, on the application of Delena Wells $v$ Secretary of State for Transport, Local Government and the Regions [2000] ECR I-723; C-152/07 Arcor AG \& Co KG, Communication Services TELE2 GmbH (C-153/07) and Firma 01051 Telekom GmbH (C154/07) v Bundesrepublik Deutschland [2008] ECR I-5959.

83 Cases C-188/89 A Foster and others $v$ British Gas plc [1990] ECR I-3313; C-6/05 Medipac-Kazantzidis AE $v$ Venizeleio-Pananeio [2007] ECR I-4557.

84 Directive 2001/18/EC of the European Parliament and of the Council of 12 March 2001 on the deliberate release into the environment of genetically modified organisms and repealing Council Directive 90/220/EEC [2001] OJ L106/1.

85 Case No M en R 2010, Council of State (25 November 2009).

86 Directive 2009/147/EC of the European Parliament and of the Council of 30 November 2009 on the conservation of wild birds [2009] OJ L20/7.
} 
there was no mention in Dutch law of gassing as a legitimate method to capture the birds, the court ruled that the national law did not provide for a sufficient legal ground to allow gassing, although the method as such did not seem to be in contradiction with the directive. ${ }^{87}$

The French Court of Cassation interpreted on a number of occasions the French Code civil in the light of the Product Liability Directive ${ }^{88}$ before the Directive was actually transposed into French law but after the expiry of the implementation period. Pursuant to Article 1147 of the Code civil, a debtor shall be ordered to pay damages if there is occasion, either by reason of the non-performance of the obligation, or by reason of delay in performing it, whenever he does not prove that the non-performance comes from an external cause which may not be ascribed to him, although there is no bad faith on his part. Further, in accordance with Article 6 of the Product Liability Directive, a product is defective when it does not provide the safety which a person is entitled to expect, taking all circumstances into account, including the presentation of the product, the use to which it could reasonably be expected that the product would be put, and the time when the product was put into circulation. By interpreting the aforementioned provision of the Code civil in the light of the Product Liability Directive, the Court of Cassation came to the conclusion that a producer is liable for a breach of his safety obligation in the event of damage caused by the product at the time when it was put into circulation and when the product does not provide the safety which could reasonably be expected given all the circumstances and, in particular, the presentation of the product ${ }^{89}$.

In the above-mentioned case, the court 'merely' gave a broader meaning to some general notion in national law in order to encompass the requirements of the directive. In some cases, the role of the national court is more complicated and it has to get down to true brain twisters. This was the case in the transposition of the Unfair Contract Terms Directive 93/13 into the Czech legal order and its interpretation by the Czech courts. The key provision of the Unfair Contract Terms Directive states that the Member States shall lay down that unfair terms used in

\footnotetext{
87 Case No LJN BM6676, District Court Utrecht (3 June 2010). For an overview of the case law of the Dutch courts on indirect effect in the area of EU environmental law, see JH Jans, 'European Environmental Law Before Dutch Courts: Observations on Direct Effect and Consistent Interpretation' (9 December 2011) <http://dx.doi.org/10.2139/ssrn.1970270> accessed 31 March 2014.

88 Directive 85/374/EEC of 25 July 1985 on the approximation of the laws, regulations and administrative provisions of the Member States concerning liability for defective products [1985] OJ L210/29.

89 Case No 03-19534, Court of Cassation (Judgment of 24 January 2006). For newer case law of the Court of Cassation on the indirect effect of directives, see Case No 12-13503 (Judgment of 17 December 2013); Case No 12-20982 (Judgment of 22 January 2014); and Case No 12-25748 (Judgment of 5 February 2014).
} 
a contract concluded with a consumer by a seller or supplier shall, as provided for under their national law, not be binding on the consumer (Article 6). The Czech courts had to resolve a number of interpretative issues in this respect, concerning the character of the abusive clauses, the enforcement of a final arbitration award against consumers, etc. One contra legem interpretation problem was caused by Section 55 (2) of the Civil Code ${ }^{90}$ which prior to the amendment by Act No 155/2010 Coll provided that the provisions in consumer contracts, as defined in Section 56 , should be deemed valid unless the consumer invoked the invalidity thereof. In other words, all the contractual provisions non-exhaustively enumerated in Section 56(3) of the Civil Code were deemed voidable (the consumer had to invoke their invalidity) until 31 July 2010; since then, they were considered null and void, regardless of whether or not the consumer invoked their invalidity. In the Opinion concerning forum-selection clauses agreed in consumer contracts, the Supreme Court of the Czech Republic ruled, that:

A court of law that arrives, when examining the conditions for the proceedings, at the conclusion that the forum-selection clause agreed in a consumer contract before July 31, 2010 that is to establish the court's local jurisdiction is in conflict with Section 56(1) of the Civil Code shall notify this to the parties to the proceedings and invite them to provide their observations on this issue within a specified period of time. The court shall rule that the forum-selection clause is voidable (Section 55(2) of the Civil Code, in the version in force until July 31, 2010) and that the procedure described in Section 105 of the Rules of Civil Procedure should be followed only if the consumer has effectively invoked the invalidity of the forum-selection clause. In the event that the consumer does not invoke the invalidity of the forumselection clause, both direct and indirect application of Directive $93 / 13$ shall be ruled out. ${ }^{91}$

Thus, the Supreme Court emphasised the obligation of the court to notify to parties the conflict of the forum-selection clause with the Civil Code provisions on consumer protection; however, declaring the forumselection clause void without any action on the part of the consumer would amount to contra legem interpretation.

\footnotetext{
90 The new Civil Code as part of the re-codification of Czech private law became effective as of 1 January 2014.

91 Case No Cpjn 200/2011, Supreme Court of the Czech Republic (Opinion of 9 October 2013). English translation available at <www.nsoud.cz>.
} 
The Supreme Court also dealt with the conform interpretation of the Arbitration Act in the light of the Unfair Contract Terms Directive. Under Section 33 of the Czech Arbitration Act, prior to its amendment by Act No 19/2012 Coll, the court would reject the application to set aside the arbitration award if the applicant had not raised its objections during the previous arbitration proceedings, before or when presenting the arguments on the merits of the case. By resorting to very strong indirect effect, the Supreme Court stated that the court cannot reject the application according to Section 33 of the Czech Arbitration Act if the applicant is a consumer. ${ }^{92}$

Certainly, the best example of how differently (or identically) the national courts of different Member States perceive the limits of indirect effect would be to compare their interpretation of similar national provisions in conformity with the same EU norm. The European Arrest Warrant saga may provide a useful example in this respect. As the constitutions of the Member States in most cases prevented the extradition of nationals or provided that their citizens may not be forced to leave their home country, the implementation measures were challenged before the national courts. While the Czech Constitutional Court adopted a very EUlaw open approach by way of a harmonious interpretation of the Czech Constitution, ${ }^{93}$ the constitutions in some other Member States (Poland, Germany) had to be amended - conform interpretation of the national constitutions was excluded as it would amount to interpreting constitutional provisions contra legem.

\subsection{Simplifying the Horizontal Application of EU Law}

At first, it has to be underlined that if the national courts were exempted from the obligation to ex officio interpret national law in the light of directives as was suggested in the previous section, the probable result would be a decrease in the number of cases concerning the (indirect) application of directives. In other words, such a measure would produce a spill-over effect, facilitating the work of national judges and simplifying the domestic application of EU law in general. In certain cases, however, national courts would still have to deal with these issues, typically when one of the parties to the proceedings (a private person) invokes a directive or a general principle of EU law expressed in a directive in a dispute against another private person. ${ }^{94}$

92 Case No 33 Cdo 1201/2012, Supreme Court of the Czech Republic (Judgment of 20 June 2013). Act No 19/2012 Coll, enacted before the Supreme Court's decision amended the Czech Arbitration Act so that the rule enshrined in Section 33 does not apply if the applicant is a consumer.

93 Case No Pl. ÚS 66/04, Constitutional Court of the Czech Republic (Judgment of 3 May 2006).

94 Under the condition that national law permits raising legal arguments at that stage of the proceedings. 
As for the general principles of EU law, notwithstanding the heated debates provoked by the Mangold-type case law and the codification of the general principles in the legally binding Charter, it seems that the application of general principles between individuals remains of limited importance for national courts. Courts of lower instances do not usually embark on far-reaching and convoluted analysis of the legal principles of the national legal system, even less the general principles of EU law. ${ }^{95} \mathrm{~A}$ number of Member States are currently engaged in the process of reform of their justice systems to render them more effective. ${ }^{96}$ The reasons are obvious: the courts' workloads are tending to rise, and more and more courts face pressure to reach quick decisions (in order to ensure, inter alia, compliance with the case law of the European Court of Human Rights) at the expense of quality. In this context, it seems likely that an ambiguous case law, as is the Court's jurisprudence on the horizontal application of general principles of EU law, will fall on deaf ears in national courts. The application of general principles of EU law could be more relevant, at least for the courts of higher instances, especially constitutional courts, which deal regularly with the scope and effects of (constitutional) legal principles and could therefore be more open to the idea of the application of general principles of EU law. The latter case law of the Court also suggests, perhaps also under the criticism of the previous case law, that the application of general principles of EU law and their application between individuals is rather restricted. For example, in Audiolux, the Court refused to recognise the equal treatment of shareholders as a general principle of EU law. ${ }^{97}$ In the above-mentioned recent case Association de médiation sociale, the Court did not grant the horizontal direct effect of the worker's right to information and consultation enshrined in the Charter. In sum, the relevance of the Court's case law on the horizontal application of general principles is questionable for the daily practice of national courts. If a national judge wants to become well-versed in this puzzling area of EU law and seeks to apply general principles in line with the Court's case law, he or she has to invest quite a lot of energy in order to properly understand the nuances of this jurisprudence (even if this is possible at all). In other words, there is a high degree of risk of misinterpreting the Court's findings, even more so when there is no general consensus about what the Court intended to say in some cases concerning the horizontal application of general principles.

\footnotetext{
95 As an illustration, it may be worth mentioning that from the 774 judgments collected by the International Department of the Czech Supreme Court for the purposes of the analysis of the application of Union law by the Czech civil courts between 2009-2011 (see footnote 43), no judgment contained a reference to the Mangold-type case law or analysis of the horizontal application of the general principles of EU law.

96 See Commission, 'The 2014 EU Justice Scoreboard' COM (2014) 155 final.

97 Case C-101/08 Audiolux SA e.a v Groupe Bruxelles Lambert SA (GBL) and Others and Bertelsmann AG and Others [2009] ECR I-9823.
} 
Having regard to the frequent occurrence of conform interpretation, the situation is different when it comes to the indirect effect of directives as a way of reaching into horizontal relationships. As previously suggested, the most complicated issue for a national judge in this regard is the potential interpretation of national law contra legem. A judge has to deal with the question to what extent the national law can be twisted, where the borderline is between conform interpretation and a complete change of meaning of a national provision.

Regarding the above-outlined case law of the national courts, several types of harmonious interpretation depending on the proximity to contra legem interpretation can be distinguished.

In the first group of cases, national law contains a general rule or a broad (legal) notion; interpreting national law in the light of a directive does not do any violence to the wording of the national provision. The above-described case law of the French Court of Cassation concerning the conform interpretation of the Code civil in the light of the Product Liability Directive can serve as an example.

The opposite extreme is when the national norm more or less clearly contradicts the norm used in a directive and the 'bending' of a national provision could very probably be regarded as contra legem. The case decided by the Council of State of the Netherlands, where the Dutch law required keeping the information about the location of GMO experiments secret whereas the relevant directive required making these data available, illustrates this quite nicely.

Between these two extremes lies quite a big group of cases where things are more ambiguous. The aforementioned decisions of the $\mathrm{Czech}$ Supreme Court on the Unfair Contract Terms Directive represents dilemmas of this kind, where opinion on whether the conform interpretation of national law amounts to contra legem interpretation would probably vary among lawyers. The Court's case law does not provide much guidance on this issue, given that it usually leaves this question to national courts except in a rather limited number of cases where the contradiction between national law and a directive is obvious. ${ }^{98}$ It is specifically this, at times, vague distinction between the indirect effect and direct effect of directives which is a source of confusion. Essentially, the Court should contribute to the clarification of these issues and to hold a rather reticent approach as to deriving extensive rights from directives capable of being invoked in disputes between individuals notwithstanding a lack of legal basis in national law. This applies also to national judges who should in

98 See Case C-334/92 Teodoro Wagner Miret v Fondo de garantía salarial [1992] ECR I-06911; Case C-286/06 Impact $v$ Minister for Agriculture and Food and Others [2008] ECR I-2483, or the above-described Association de médiation sociale (n 73). 
these borderline cases attempt to find a solution respecting the difference between the indirect and direct effect of a directive and to avoid a decision that would surprise the parties. Moreover, except for cases of full harmonisation, the character of directives in principle allows national judges when dealing with the indirect effect of a directive to adopt a solution which is in tune with national needs and reflects national particularities, and judges should feel encouraged to do so. To use the example of the indirect effect of EU consumer legislation, the extent to which a national judge will interpret national law in the light of EU directives may depend presumably (among other things) on the traditional level of consumer protection in a given Member State (arguably, this level varies among Member States). Unless any systematic solution is provided, the 'simplification' can more or less consist only in providing these rough guidelines, reminding national judges that the main characteristics of a directive, as an (mere) indirect form of legislation, should preferably be preserved.

The Court has created a number of loopholes in the prohibition of the horizontal direct effect of directives. Although these exceptions might have been justified by circumstances in individual cases, in terms of the domestic application of EU law the Court's approach is not desirable. The cases where the Court adheres to its settled case law usually do not appear in the spotlight; by contrast, the controversial ones are intensively discussed and therefore more noticeable. In these cases, the Court occasionally uses general principles to circumvent the prohibition of the direct effect of directives or it blurs the distinction between indirect and direct effect (eg in some consumer cases where the indirect effect of certain consumer directives almost amounts to direct application in the Court's interpretation). These inconsistencies may contribute to the confusion of national judges and to divergences in national practice. After all, it comes as no surprise that we can from time to time encounter judgments of national courts in which they apply directives in the disputes between individuals without any hesitation.

It follows from the above that it is predominantly up to the Court to take into account the particularities of the application of Union law in the Member States and to try to keep the rules governing the application of EU law between individuals simple and clear. This holds true mainly for the case law on general principles which represents a good source of inspiration for academic writing but is less suitable for implementation by national courts. If parties to the proceedings do not know which of the general principles of EU law are going to be applicable, they cannot frame their disputes in national courts, and, consequently, national courts are left without appropriate guidance. Therefore, it should be sufficiently specified which general principles of EU law may be applied in private disputes and under what circumstances; preferably, their applicability 
should be restricted. As for the intricacies of contra legem interpretation, the concerted and strengthened effort of European institutions and national authorities to ensure the better compliance of national transposition provisions with the directives, as proposed in the previous section, should contribute to a decrease in the number of cases where national courts encounter difficulties in interpreting national law in the light of directives.

\section{WHY: Enhancing the proper application of EU law in the Member States}

There is a little doubt that continuing European integration will lead to the growing complexity of the Union's legal order. Accordingly, as the EU expands, the range of its activities and the number of legislative acts adopted by the EU will steadily grow. With this perspective, it can be assumed that the role of national judges in enforcing EU law within national legal orders will continue to bear importance.

As previously suggested, even after decades of European integration and the simultaneous application of European law in the Member States, the number of yet undetermined issues and misinterpretations concerning the principles of the domestic application of Union law remains surprisingly high. Still, misconceptions about the principle of supremacy of EU law can be observed, ${ }^{99}$ and national judges cannot be entirely sure when the principle of effectiveness should prevail over the principle of equivalence in the area of procedures and remedies for the enforcement of EU law based rights, when the court has to raise points of EU law of its own motion, how to apply some EU legislation in relations between private persons, what the limitations of the application of legal principles between individuals are, what the scope of the obligation is to revoke a national final administrative decision or judgment which is not compliant with EU law, ${ }^{100}$ etc.

It would probably be an exaggeration to say that we are witness to some sort of systematic loophole in the application of EU law in the Member States. On the other hand, the signs that show that disregard for EU law or the incorrect application of Union law in national proceedings are nothing uncommon should not be ignored either. Before considering potential solutions and proposals for improvement, one should not forget to explore the possible reasons for the current situation. For sure, it is rath-

\footnotetext{
99 S Prechal (n 45).

100 Cases C-224/97 Erich Ciola v Land Vorarlberg [1999] ECR I-2517; C-453/00 Kühne \& Heitz NV v Produktschap voor Pluimvee en Eieren [2004] ECR I-837; Joined Cases i-21 Germany GmbH (C-392/04) and Arcor AG \& Co. KG (C-422/04) v Bundesrepublik Deutschland [2006] ECR I-8559.
} 
er a conglomeration of factors that determine the current state of things, ranging from the education and training of legal professionals in EU law to the sometimes excessive and chaotic legislative activity of the Union. Ideally, national judges should embrace EU law in the same way as they do the norms of their national legal order. Various institutional measures can be adopted to enhance the awareness of national judges, for example introducing training programmes or introducing legal clerks specialized in EU law in courts. The issues of the principles of the domestic application of EU law are sometimes overlooked in this respect. Undoubtedly, national judges are professionals designated to manage the complicated legal cases and they should be able to cope with the demanding requirements imposed upon them. However, EU law at times imposes upon national judges very burdensome obligations which may, as practice shows, discourage them from applying EU law at all. Simplification of the principles of the domestic application of EU law seems a logical step to increase the willingness of national courts to apply Union law. Consequently, EU law would arguably be applied more frequently in a correct manner. One should not forget that, besides courts, all national authorities are also bound to apply EU law; unlike in the courts, there are many officers and clerks of the national (often local) authorities who are not lawyers and who are not educated in law at all. This should also be taken into account when formulating the basic principles of the domestic application of EU law. At the same time, better monitoring of the domestic application of EU law by the Commission, possibly in joint cooperation with responsible national authorities, is something to consider. Until now, the Commission has been rather reluctant to bring infringement proceedings for the wrong application of EU law by national courts. ${ }^{101}$

Simplification of the domestic application of EU law as proposed in the previous sections is by no means an all-embracing solution. It should rather be viewed as another piece of the jigsaw of possible improvements to be adopted to enhance the proper application of EU law.

\section{Conclusion}

The ever-growing complexity of the legal environment in contemporary Europe makes it no longer tenable to hold the picture of a judge as a specialist who has extensive knowledge of national, European and international law and knows how to apply it within the polycentric legal order. Moreover, with regard to the number of pieces of EU legislation enacted every year, the expected result is the further deepening of these intricacies.

${ }^{101}$ See for instance Case C-154/08 Commission of the European Communities $v$ Kingdom of Spain [2009] ECR I-00187. 
In this context, the question which arises is not only about how to instruct and train national judges in order to enhance the proper application of EU law, but also what can be done by national authorities and European institutions in this regard. Easing the burden on national judges by simplifying the principles of the domestic application of EU law is not an act of compassion but rather of rationality - judges will be more inclined to acquire these principles when they are simpler. The idea of a district court judge who is concerned on a daily basis with the performance of contextual tests, searching for unimplemented or incorrectly implemented directives, or tinkering with general principles of EU law, does not seem very realistic.

The aim of this paper was to attempt to show that there are potential avenues to take to deal in a simplified way with the domestic application of EU law, namely with the obligation to apply EU law ex officio, and the application of EU law between individuals. As national courts are the only authorities (besides administrative bodies) capable of ensuring the effectiveness of EU law in daily legal practice, more attention needs to be paid in the years to come to these issues by academia as well as by EU institutions and national authorities. 